\title{
On the Anti-Japanese Narrative of Beast Train
}

\author{
Hong-Hua DENG ${ }^{1 *}$ \\ ${ }^{1}$ Department of Chinese language and literature, Pingxiang College, Pingxiang, 337000 \\ dredflower@163.com \\ ${ }^{\star}$ Corresponding author
}

Keywords: anti-Japanese drama, Beast Train, narration of settings, alternative

\begin{abstract}
The anti-Japanese drama of Beast Train told the thrilling story that the captain Lin Zijun of Anti-Japan union and Police Tong Xiaole track gold and biochemical virus. This paper expounds particular characteristics narrative of Beast Train such as multi-line, paying attention to scene narration, and the first-person narrative. Beast Train's narration of settings is alternative in compared to other anti-Japanese drama.

Chinese people have learned a lot from the history about the anti-Japanese War. The anti-Japanese dramas have been performed on the screen in China. For the anti-Japanese drama, a lot of people have veiled criticism and think the anti-Japanese dramas are untrue. They call them anti-Japanese god drama. In fact we watch any film and television works derived from reality after processing all kinds of fiction. "If there is no drama, fiction, no story, there is no film". The audience is demanding that the TV play must absolutely follow the history. Then the TV play will turned into a documentary, rather than a war movie for the war has become history. The anti-Japanese War drama is based on the true history of the anti-Japanese War. The opera shows a certain ending that the war achieved the victory of justice over evil from different angles and methods. The anti-Japanese drama shapes various anti-Japanese heroes from basing on respect history, and some fictional aspect. It is in line with the film aesthetic needs of audience.

There were many anti-Japanese drama 1n 2014. There is slightly different in Beast Train. Beast Train is very unique on the narrative such as multi-line narration, paying attention to scene narration, and the first-person narrative. Beast Train's narration of settings is alternative in compared to other anti-Japanese drama.
\end{abstract}

\section{Player Used A Multi-Line Narration throughout the Play.}

Beast Train tells the story in the early 1930s that Japan had occupied three provinces in northeast China.

On a train from Harbin to FengTian, Japanese secretly transported relevant biochemical experts and important material in germ warfare preparing on the one hand. On the other hand the central bank of South Manchurian puppet government wanted to transport large quantities of gold by railway. Special agent of the Kuomintang whose code name is Crow planed to blow up the train to capture gold.

The Kuomintang DongMing wanted to possess gold. Around the gold on the train, ombudsman ChenJin of Manchukuo, the brother of Crow, Chen Dapao led a special force to search for gold and kill DongMing. In addition, the Communist Party's secret stronghold also was attacked by Crow, so the anti-Japanese union planned to capture Crow. They want to put the gold into the anti-Japanese materials, and to protect the innocent passengers on the train. And the abjection warlords WangFuxing want to take to revive his Army Corps by capturing the gold when he heard the gold of the train. The parties focus together. They staged a war around the train, the gold and the virus on South Manchuria Railway of more than six hundred km long.

Black Tooth in the train and the gold were the main clue, and the rest of the clues being around the train to happen. If we use a chart to indicate, the narrative clues like as a fish skeleton. Biochemical in vivo on the train was escorted by the Japanese Kwantung Army in secret with Kitagawa Miyuki and 
the twelve spies who carry the twelve signs of the zodiac. At the beginning Kitagawa Miyuki and twelve spies with gold zodiacs who dressed as passengers hiding in the shadows eliminated the risk and protected black tooth and virus formula to FengTian. An American sitting across from Kitagawa Miyuki was an investigator of international biological and chemical weapons. The investigator had found that Japan had developed a biological weapon in secret, and he used a miniature camera to shoot the biochemical evidence which were the biochemical evidence. The biochemical evidences were some photos in which some of the soldiers and passengers infected with the virus and died of a virus infection. When investigator found the identity of Kitagawa Miyuki, Kitagawa Miyuki also wised up to the investigator's identity. Kitagawa Miyuki used her pet dog to scratch investigator and poison investigator. In his temporary, he put miniature film with the envelope in the buffet car. The Japanese soldiers were accidentally scratched by "black tooth" and infected with the virus. The poisonous vomiting blood spattered on the diner's wine, resulting in dining carriage of passengers. They were infected with the virus, of which one is Anti-Japan Union member named SanZhao. SanZhao was directly spattered to the lips by Japan poison blood. Passengers who have been poisoned were transferred to the conductor by Lin Zijun. When one passenger who was a spy attempted to leave with gold zodiac, SanZhao strangled him. On the other side, Lin Zijun went to a secret compartment to find the antidote, accidentally learned biochemical virus thing. Finally all passengers died of poisoning. A Japanese officer sent the Japanese soldiers Japanese soldiers having been poisoned to DeHai hospital during train parking.

So another clue to DeHai came into being from the train. There had been slaughtered in DeHai hospital. The mayor Tan Haibo was asked by the crowd. When Tan Haibo find out the secret of Japan using chemical and biological weapons, he was ready to report to leadership. Then he was imprisoned by the Japanese. After the Japanese killed his wife and daughter, he killed Japanese soldiers and committed suicide. Tan Haibo left a letter for the ombudsman ChenJin before he was imprisoned by the Japanese. He told biochemical virus, and corruption of Manchukuo, the Japanese bossy to ChenJin. ChenJin determined to find gold and destroyed the virus. On the other side, the younger brother of Crow who wanted to find out the murderer of killing his older brother and ChenDapao were grappling with DongMing and the gold. ChenDapao forced the train to stop. ChenDapao was countered during the negotiation with Japanese. When ChenDapao met Lin Zijun and Tong Xiaole, they decided to destroy the virus in vivo together, and look for the formula of the virus in the gold pendant. Party members of the abjection warlords WangFuxing stumbled into the virus train for the lure of gold and kidnapped Kitagawa Miyuki. Unfortunately they failed to kill Kitagawa Miyuki. Tong Xiaole and Lin Zijun found eleven spies who carried gold zodiac on the train. In fact, Kitagawa Miyuki's gold zodiac was really useful. The last spy carrying gold zodiac was Cheng Dayun who was Tong Xiaole's good friend. In order to get the antidote, Cheng Dayun wanted to kill Tong Xiaole and get a gold zodiac. eng Dayun killed SuJian finally and got a gold zodiac. But he was ambushed and killed by the Japanese. The last of the virus was destroyed by Lin Zijun, and the passengers on the train were rescued. This fish skeleton narrative dendrites cluster more, but the main clue is around the train of gold, the virus to spread.

\section{Now it is time to analysis the narration of settings.}

It was a single scene tracking play. With previous tracking play the difference was that "Beast Train" mainly happens on the scene of a single train, but because of the motion of the train, the situation is changing. Other all sorts of forces were chasing trains. It is different from other TV series on narrative scene. This narrative is similar to Phone Booth and Buried. Three dramas are in the constantly changing situation although in a single fixed scene. The narrative scenario exists complex relationships between space and power.

Television footage of Chen Dapao shelling train was similar to the Phone Booth. The fight of Chen Dapao and Kitagawa Miyuki embodied the subtle complex relationships between space and power. Chen Dapao in the dark stalemated with Kitagawa Miyuki. Because of being afraid to kill the living 
Black Tooth, Kitagawa Miyuki had to compromise with Chen Dapao. Then several other spies of Kitagawa Miyuki with gold Zodiac easily killed Chen Dapao's special forces. Chen Dapao not only hurt Kitagawa Miyuki and Black Tooth alive, but did not get rid of traitor DongMing. Lin Zijun and TongXiaole worried about passengers' safety. They killed the ambush soldiers of Chen Dapao on high and get rid of the spy with gold zodiac on the way. For Chinese nation's sense of honor Chen Dapao and Lin Zijun decided to catch the train where there is a biochemical virus. In addition to the sniper scene on the road, the whole train for both sides in the war is a battle of open strife and veiled struggle. Especially the spies with gold zodiacs of Kitagawa Miyuki scattered in every hidden corner, which made each space environment be threatened by growing crises. The spies with gold zodiac included the conductor, dwarf, agents and Cheng Dayun who is TongXiaole's good friend. To be surprised, there was a paper of virus formula in Kitagawa Miyuki's gold zodiac. Other gold zodiacs were used for stealth.

There were some comedy scenes. There were also some gag scenes in the play, mainly joking the chasing gold setting about the soldiers of the abjection warlords WangFuxing. WangFuxing's soldiers found gold unintentionally and clashed with ChenJin along the way. So ChenJin thought there was a strong association between DongMing, gold in the train and corruption in the upper level of Manchuria. WangFuxing's soldiers got a real good result accidentally. When Kitagawa Miyuki banqueted the dangerous passengers that she thought, she also brought a few spies with gold zodiacs who mixed into the dangerous passengers in order to find some dangerous men. In fact Kitagawa Miyuki didn't know the gold in the train until DongMing told her for his own life. Moreover WangFuxing's soldiers sneak into successfully sneaked into the train. There was a banter scene in the dining car. The warlords of WangFuxing's soldiers took control of Kitagawa Miyuki beside the table. They used the overpowering drug to diners and controlled Kitagawa Miyuki. But the soldiers missed chance to kill Kitagawa Miyuki in order to save WangFuxing.

There were some sudden turn scenes in Beast Train. The TV play of Beast Train also used the various scenarios of sudden turn. It makes the reader feel exceeding their expectations and be taken by surprise. After Tong Xiaole was arranged in the cold store to guard the gold by DongMing, the military adviser of Wang Fuxing broke into the cold store and fought with Tong Xiaole. Dong Ming sent killer to kill Tong Xiaole, mistakenly stabbed army adviser, but saved Tong Xiaole from the crisis. When Tong Xiaole and Lin Zijun caught the train, they met a teenage child. Lin Zijun cared for him as a child. But when the children sawr the gold zodiacs, he turned nasty.The child wanted to kill them. The child was actually an adult who was a Japanese agent. These unexpected scenes enhance TV story to be very infectious, and win the audience's attention.

\section{Conclusion}

In short, there was a multi-line narration throughout the play. The TV drama of Beast Train used a single closed scene to enhance the story's infection. It is alternative in compared to other anti-Japanese dramas.

In addition, the narrative perspective of Beast Train is based on Lin Zijun's first person narrative perspective. The first task of the anti-Japanese captain Lin Zijun was destroyed by the Crow. In the process of tracing gold she saw Tong Xiaole how to become a hero from a careless and casual man during the working hours. Tong Xiaole had a heart of justice, but fight when he can win, move away when he can't win. For the safety of the passengers, the gold, and destroyed the virus, Lin Zijun and Tong Xiaole fought a battle of wits. They brought passengers out of danger and smashed biochemical virus successfully. It realized the transformation of Tong Xiaole from a small character to the hero.

\section{References}

[1] Xiaopeng Gong Comparison of the narrative mode of war movie Sino US against Japan [J] Shandong Social Sciences (2012) No.4. 59-62. 
[2]Yidu Lv. On the narrative power of war in the Chinese war film [J] Journal of PLA Academy of Art (2012) No.4. 29-36.

[3] Lihong Guo. War narration in the context of Post Modernism [J] Movie Literature (2009 )No.20. 110-111.

[4]Maozeng Li. HuaWen. On narrative of war and national imagination [J]. Journal of PLA Academy of Art (2009) No.4. 34-39.

[5] Nan Zhang. Deactuality of war narratives in contemporary arts [J] Journal of Northwest University(Philosophy and Social Sciences Edition) (2012) No.6.127-131.

[6] Juan Huang. Reflection on revisit and restudy: history, context and theory [J] Journal of China Agricultural University(Social Sciences Edition) (2014 )No.1.100-107. 